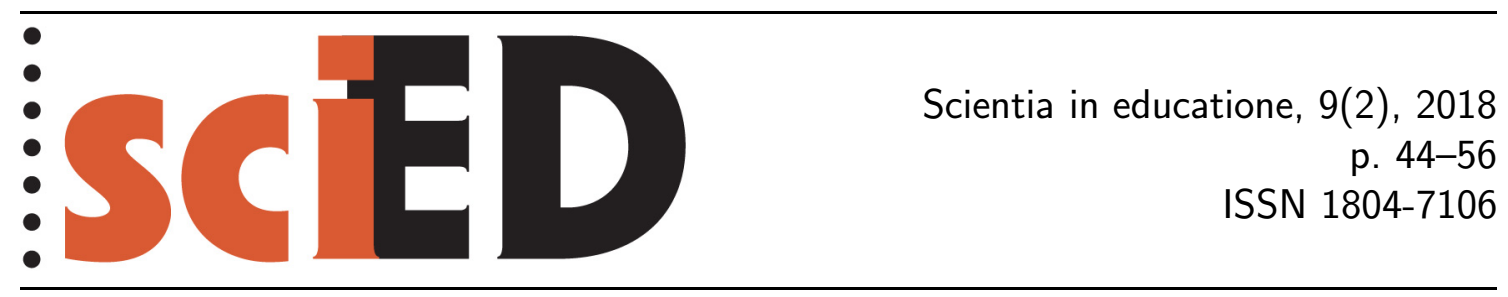

\title{
Obliba školní matematiky a její souvislost s externím hodnocením a sebehodnocením
}

\author{
Irena Smetáčková
}

\begin{abstract}
Abstrakt
Obliba matematiky je důležitým faktorem ovlivňujícím motivaci ke školním úkolům, a tedy i samotné školní výkony žáků. Článek se zabývá otázkou, zda a nakolik obliba matematiky souvisí bud's externím hodnocením v podobě známky z matematiky na vysvědčení a výsledku v matematickém testu, nebo s žákovským sebehodnocením v podobě pocitu matematické kompetence a dlouhodobé matematické self-efficacy. Studie se zúčastnilo 1383 žáků a žákyň od 4. do 9. ročníku základních škol, kteří vyplnili didaktický test a žákovský dotazník. Analýza ukázala, že obliba matematiky s věkem klesá a je nižší u dívek než u chlapců. Dále se potvrdilo, že nízká obliba matematiky souvisí s horší známkou, horším výsledkem v testu, nižším pocitem kompetence i nižší matematickou self-efficacy. Externí hodnocení mělo výrazně nižší prediktivní hodnotu než žákovská sebehodnocení.
\end{abstract}

Klíčová slova: matematika, obliba, úspěšnost, známka, self-efficacy.

\section{Preference of School Mathematics and its Link to External Evaluation and Self-evalutaion}

\begin{abstract}
The popularity of math as a school subject is a crucial factor fostering educational motivation and student performance in the subject. This paper seeks to answer the question as to whether the popularity of math is related to either external evaluation (final math exam assessment and the student's achievement in a didactic test) or internal self-evaluation (the student's confidence in his or her math competence and mathematical self-efficacy). The study examined a total of 1383 students, spanning $4^{\text {th }}$ through $9^{\text {th }}$ grades of grammar school, who answered the questionnaire and took the mathematical test. The analysis showed that math popularity was decreasing across age groups - older students preferred math significantly less than younger students; and also with regard to gender, as female students preferred math significantly less than male students. Moreover, it showed that the low math popularity was statistically connected to a worse grade, worse test results, the student's weaker confidence in his or her math competence, and also weaker math selfefficacy. The external evaluation (test results and the final assessment on the student's report card) had a significantly lower predictor function than internal self-evaluation.
\end{abstract}

Key words: math, popularity, success, grade, self-efficacy. 
Míra, v jaké žáci vnímají matematiku jako svůj oblíbený školní předmět, souvisí s tím, jak se jim reálně v tomto předmětu daří. Např́ílad Mullis a kol. (2012) prokázali na datech z TIMSS 2011, že existuje jasný pozitivní vztah mezi výsledky v matematickém testu a oblibou matematiky. Obliba má tedy vazbu k výkonům, přičemž tato vazba je zprostředkována motivací. Obliba představuje specifický typ školní motivace, který posiluje snahu i př́mo facilituje výkony v řešených úkolech (Inzlicht \& Schmader, 2012).

Existující zahraniční i české studie potvrzují, že obliba školní matematiky v porovnání s ostatními předměty je relativně nízká. Pavelková a Hrabal (2010, 2012) opakovaně ukázali, že matematika je českými žáky vnímána jako silně neoblíbený předmět. Zároveň ho považují za velmi obtížný předmět a získávají v něm nejhorší školní hodnocení. To by naznačovalo, že obliba vyplývá ze subjektivní obtížnosti/snadnosti předmětu a z úspěšně/neúspěšně hodnocených výkonů. Tyto studie také ukazují, že v průběhu 2. stupně základní školy dochází k výraznému snižování obliby matematiky. Nalezen byl navíc rozdíl mezi dívkami a chlapci, přičemž chlapci považují matematiku za oblíbenější a méně obtížný předmět než dívky (Pavelková \& Hrabal, 2012).

Zhoršování vztahu k matematice v průběhu základní školy potvrzují i další výzkumy. Například analýzy Chvála (2013) ukazují, že na počátku 2. stupně ZŠ nastává výrazný propad v oblibě. Obliba matematiky koresponduje s celkovým vztahem ke škole, který se rovněž zhoršuje s narůstajícím věkem, jak zjistila analýza Federičové a Münicha (2015). Tento autorský tým na mezinárodním srovnání navíc ukázal, že v př́padě českých žáků je pokles obliby školy i matematiky o něco silnější. Také je podle nich v českém prostředí patrná užší souvislost mezi negativními postoji chlapců ke škole a vzdělávacími výsledky, přičemž žáci se slabými školními výsledky vykazují zvláště silnou neoblibu. Důležité přitom je, že faktory na straně učitelů a škol vysvětlují jen velmi nízký podíl variace obliby (Federičová \& Münich, 2015).

Je proto důležité blíže prozkoumávat další zdroje, na základě kterých si žáci budují oblibu školní matematiky. Tento článek se však nezabývá tím, z jakých předmětových charakteristik obliba předmětu vychází (např. osobnost učitele, vyučovací metody, velikost žákovské skupiny atd.), nýbrž tím, jaký vztah má obliba matematika s externím a interním (subjektivním) hodnocením, které je se školní matematikou spojeno. Důvodem, proč se zaměřujeme na hodnocení coby vnější a vnitřní zpětnou vazbu na matematické výkony, kterou žáci získávají od okolí či poskytují sami sobě, je skutečnost, že jak hodnocení, tak obliba mají společného jmenovatele, a tím jsou emoce. Hodnocení stejně jako obliba se vždy pohybují v pozitivních či negativních intencích. Předpokládáme proto, že by mezi hodnocením a oblibou mohly existovat úzké vazby. Otázkou však je, jak silné tyto vazby jsou, a to jak celkově, tak u jednotlivých typů hodnocení.

$\mathrm{Na}$ základě poznatků z předcházejících výzkumů (např. Ramdass \& Zimmerman, 2008) jsme v našich úvahách rozlišili externí hodnocení, kdy žáci získávají víceméně nezávislou zpětnou vazbu na své výkony, a to v podobě školní známky na vysvědčení nebo v podobě výsledku v matematickém testu, a interní (subjektivní) sebehodnocení, kdy si žáci utváří vlastní přesvědčení o svých schopnostech, a to bud' v podobě relativně nestrukturovaného pocitu vlastní matematické kompetence, nebo komplexní a dlouhodobější matematické self-efficacy. Jinými slovy, externím hodnocením se rozumí školní zpětná vazba, kterou žáci získávají od vyučujících, a případně výsledky $\mathrm{v}$ testech vytvářených organizacemi mimo školu, zatímco interním hodnocením se rozumí subjektivně utvářená žákovská představa o vlastních 
znalostech a dovednostech na základě interpretace vnějších hodnocení i vnitřních pocitů z výkonů (Usher \& Pajares, 2009; Smetáčková \& Vozková, 2016; Chvál, 2013; Hrabal \& Pavelková, 2010).

\section{CharakteristikA STUdie}

Cíl

Studie představená v tomto článku se zabývá vztahem mezi oblibou a hodnocením ve školní matematice. Jejím cílem je zjistit, nakolik obliba matematiky souvisí s hodnocením matematických kompetencí žáki̊, a to s ohledem na věk a gender. Hodnocení matematických kompetencí může mít bud' externí charakter (hodnocení od vnější autority), nebo sebehodnotící charakter (hodnocení samotného žáka). Studie sledovala následující výzkumné otázky:

- Jaký je vztah mezi oblibou matematiky a externím hodnocením?

- Jaký je vztah mezi oblibou matematiky a interním hodnocením?

- Liší se vztah mezi oblibou a hodnocením v matematice u dívek a chlapců?

- Liší se vztah mezi oblibou a hodnocením v matematice mezi staršími a mladšími žáky?

V naší studii jsme použili následující čtyři ukazatele hodnocení matematických kompetencí:

1. školní prospěch v podobě známky na vysvědčení (dlouhodobé externí hodnocení),

2. aktuální úspěšnost $\mathrm{v}$ řešeném matematickém testu,

3. pocit vlastní kompetence $\mathrm{v}$ předmětu (Matematika mi jde),

4. matematická self-efficacy (vnímaná osobní zdatnost v matematice).

Sledovali jsme, který z těchto ukazatelů má nejsilnější souvislosti s oblibou matematiky. Zajímalo nás, zda se samotná obliba, jednotlivé ukazatele hodnocení a síla jejich vzájemné vazby liší podle věku (tj. od 4. do 9. ročníku základní školy) a podle genderu (tj. mezi žákyněmi a žáky).

$\mathrm{Na}$ základě dosavadních poznatků představených $\mathrm{v}$ teoretických východiscích jsme formulovali následující tři hypotézy:

- S narůstajícím věkem klesá obliba matematiky (Hypotéza 1)

- Chlapci považují matematiku za oblíbenější předmět než dívky (Hypotéza 2)

- Obliba matematiky silněji souvisí s matematickou self-efficacy než s prospěchem, pocitem vlastní kompetence a aktuální úspěšností (Hypotéza 3).

\section{PRŮBĚH}

Studie vznikla v rámci výzkumu, který se zabývá žákovskou úspěšností ve slovních úlohách a zjištuje, jaké jazykové a matematické parametry vedou k úspěšnému či naopak méně úspěšnému řešení slovních úloh. Ve výzkumu jsou zařazeni žáci čtyř pražských základních škol, kteří se průběžně účastní testování. Zapojené školy se liší svojí velikostí, zaměřením, lokalitou a dalšími parametry, takže výsledný soubor je dostatečně pestrý. V rámci jednotlivých škol se obvykle zúčastnily všechny třídy či jejich většina (vynechány byly pouze třídy, kde vyučující projekt považovali pro žáky či pro sebe za prř́liš zatěžující). Na začátku výzkumu všichni žáci prošli vstupním 
testem, který zahrnoval sadu slovních úloh odpovídajících zvládnutému kurikulu $\mathrm{v}$ př́śslušných ročnících zúčastněných škol a $\mathrm{k}$ nim přiřazených příkladů ověřujících zvládnutí matematických operací tak, aby bylo možné odlišit, zda žáci selhávají v samotných operacích, či jejich aplikaci v rámci slovní úlohy.

Vstupní test v krátkém časovém odstupu doprovázel žákovský dotazník, který mimo jiné mapoval postoje $\mathrm{k}$ matematice. Konkrétně se jednalo o oblibu matematiky, odhad vlastní kompetence, zkrácenou škálu matematické self-efficacy, známku na vysvědčení a dále oblibu konkrétních celků učiva, oblibu slovních úloh, postupy při řešení slovních úloh, koníčky a obeznámenost s vybranými reálnými situacemi. Všechny údaje poté byly převedeny do elektronické podoby, kde odpovědi z dotazníku a úspěšnost $\mathrm{v}$ testu byly propojeny, aby umožnily srovnání souvislosti mezi oběma proměnnými. V rámci zpracování výsledků ze vstupního a následných testování byla použita také IRT (item-response theory), která však nemá opodstatnění ve zde prezentované studii. Ta využívá výsledky zpracované na základě klasické teorie testi̊.

\section{VÝZKUMNÝ SOUBOR}

Výzkumu se zúčastnilo celkem 1383 žáků a žákyň ze šesti ročníků čtyř základních škol. Školy byly vybrány na základě zpráv ČS̆I a vlastních webových stránek. Snahou bylo zvolit školy s průměrnými výsledky v matematice a navíc tak, aby se jednalo o středně velké školy ze širší Prahy, aby do nich docházeli žáci z bezprostředního okolí s pestrým socio-kulturním zázemím a aby podíl žáků-cizinců nepřevyšoval průměr ČR. Dále jsme zohledňovali, aby se nejednalo o školy s navýšeným počtem hodin matematiky a aby školy nebyly specificky zaměřeny na práci s určitou skupinou žáků se speciálními vzdělávacími potřebami.

Jednání nejprve probíhalo s vedením škol, které poté předalo kontakt na konkrétní vyučující jednotlivých ročníků. Samotní žáci a žákyně byli o výzkumu informováni vyučujícími a poté zadavateli během samotného testování. Žáci i jejich rodiče měli možnost účast ve výzkumu odmítnout. Ze studie byli vyloučeni ti, kteří se nezúčastnili testování či vyplnění žákovského dotazníku (at již z důvodu absence, nebo nesouhlasu).

Složení výzkumného souboru pro zde prezentované analýzy uvádí tab. 1. Nevyrovnané zastoupení jednotlivých ročníků je zapř́ičiněno aktuálním počtem tříd v zúčastněných školách. Počty žáků v jednotlivých ročnících jsou však dostatečné na to, aby mohly být prováděny analýzy s ohledem na věk, resp. na ročník. Stejně tak i zastoupení dívek a chlapců je dostatečné pro analýzy s ohledem na gender, a navíc odpovídají jejich podílům v cílové populaci.

Tab. 1: Složení výzkumného souboru

\begin{tabular}{crrr}
\hline Ročník & $\begin{array}{c}\text { Počet } \\
\text { celkem }\end{array}$ & $\begin{array}{c}\text { Počet } \\
\text { dívek }\end{array}$ & $\begin{array}{c}\text { Počet } \\
\text { chlapců }\end{array}$ \\
\hline 4 & 301 & 154 & 147 \\
\hline 5 & 300 & 150 & 150 \\
\hline 6 & 243 & 125 & 118 \\
\hline 7 & 180 & 88 & 92 \\
\hline 8 & 209 & 103 & 106 \\
\hline 9 & 150 & 88 & 62 \\
\hline Celkem & 1383 & 708 & 675 \\
\hline
\end{tabular}




\section{VÝSLEDKY}

\section{OBLIBA MATEMATIKY}

Základní sledovanou proměnnou byla obliba matematiky coby školního předmětu, která byla zjištována na třístupňové škále od oblíbený předmět (1) přes nevadí mi (2) po neoblíbený predmět (3). Tato škála byla zvolena proto, že se ukázala být reliabilní v předcházejících výzkumech a že její znění je dostatečně jednoduché, aby mu rozuměli i žáci nejmladších ročníků. Podíl žáků, kteří zvolili při hodnocení obliby matematiky jednotlivé odpovědi, je uveden v grafu 1.

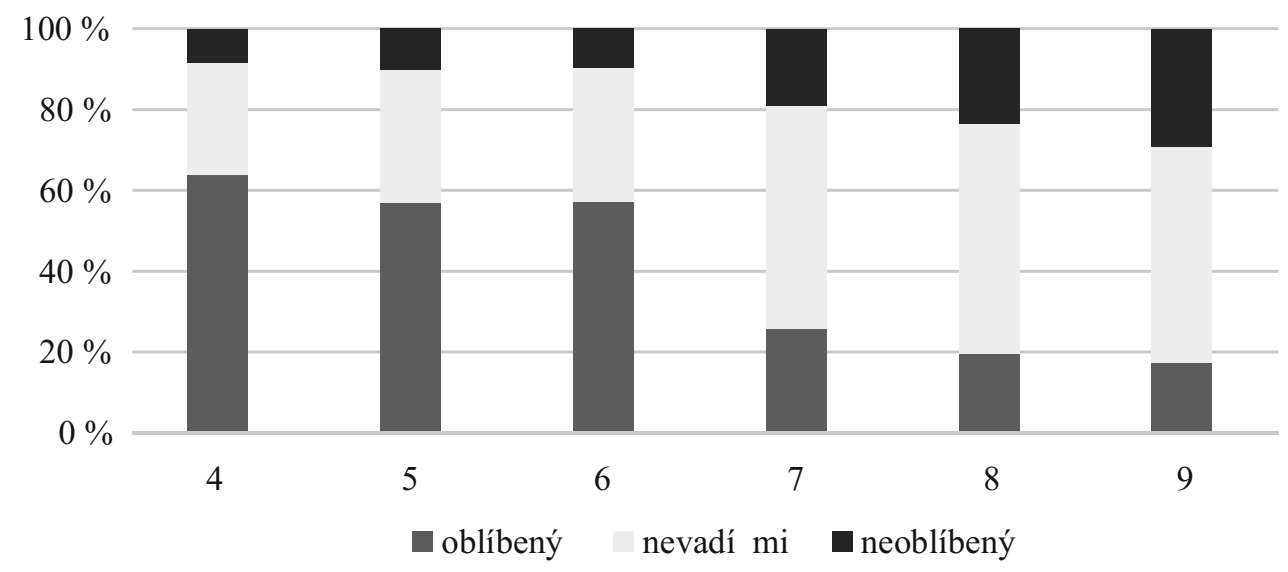

Graf 1: Podíl míry obliby matematiky u žáků 4. až 9. ročníku

Z grafu jasně vyplývá, že matematika coby neoblíbený předmět má s věkem vzrůstající tendenci. Zatímco na konci 1 . stupně základní školy je matematika neoblíbeným předmětem jen pro zhruba $10 \%$ dětí, na konci 2 . stupně pro téměř $30 \%$. Naopak oblíbeným předmětem je nejprve pro více než $60 \%$, ale posléze pro přibližně $25 \%$ žáků.

Dívky a chlapci se v oblibě matematiky lišili - dívky považovaly matematiku za méně oblíbenou než chlapci. Dívky dosáhly průměrného skóru 1,77 $(S D=0,733)$ a chlapci $1,60(S D=0,685)$ na tř́bodové škále. Tento rozdíl je statisticky významný, $t(1361)=4,369, p<0,001$. Ačkoliv celkové výsledky ukazují signifikantní rozdíl, při detailním pohledu do rozdílů mezi dívkami a chlapci v jednotlivých ročnících jsou signifikantní jen pro 5. ročník $(p<0,001)$ a 8. ročník $(p<0,05)$. Z toho vyplývá, že genderové rozdíly sice existují, ale jejich velikost není zcela zásadní.

\section{ÚSPĚŠNOST V MATEMATICKÉM TESTU}

V každém ročníku byl použit jedinečný matematický test, který odpovídal probíranému učivu. Napříč ročníky však testy měly obdobnou strukturu - vždy obsahovaly 3 až 5 slovních úloh a stejný počet početních příkladů. Všechny úlohy byly otevřené, takže žákovská řešení musela být vyhodnocena a teprve poté převedena do elektronické podoby. Účelem testu bylo roztřídit žáky podle úspěšnosti pro další kola testování. Obtížnost úloh proto byla zvolena tak, aby test jako celek mezi žáky dobře diskriminoval. Př́liš snadné a př́liš obtížné úlohy nebyly do testu zařazeny. Úlohy byly před zařazením do testů pilotovány, ovšem testy jako celky již další pilotáží neprošly. Navíc nebylo možné zcela zaručit, aby aktuálně probírané učivo na jednotlivých školách bylo zcela shodné. Ačkoliv tedy úlohy ověřovaly vždy jen takové učivo, u něhož byla jistota, že jej žáci již mají zvládnuté, v některých třídách se 
Tab. 2: Úspěšnost v matematickém testu

\begin{tabular}{ccccccr}
\hline & \multicolumn{2}{c}{ Průměrná úspěšnost v $\%$} & \multicolumn{2}{c}{ Směrodatná odchylka } \\
\hline Ročník & Celkem & Dívky & Chlapci & Celkem & Dívky & Chlapci \\
\hline 4 & 69,8 & 67,4 & 72,4 & 0,171 & 0,186 & 0,151 \\
\hline 5 & 78,4 & 78,9 & 78,0 & 0,178 & 0,168 & 0,187 \\
\hline 6 & 64,5 & 62,3 & 66,9 & 0,240 & 0,244 & 0,235 \\
\hline 7 & 58,8 & 54,4 & 62,9 & 0,254 & 0,249 & 0,254 \\
\hline 8 & 62,1 & 57,4 & 66,6 & 0,265 & 0,273 & 0,249 \\
\hline 9 & 56,1 & 54,3 & 58,6 & 0,234 & 0,225 & 0,246 \\
\hline Celkem & 66,7 & 64,2 & 69,2 & 0,231 & 0,237 & 0,223 \\
\hline
\end{tabular}

jednalo o učivo momentálně vyučované, zatímco v jiných již dobře ukotvené. Tento fakt mohl způsobit diskrepance výsledků mezi ročníky, které jsou patrné v tab. 2.

Z této tabulky vyplývá, že celková úspěšnost v testech byla $66,7 \%$, což odpovídá očekávání a potřebám vysoké diskriminační schopnosti testu. Rovněž v jednotlivých ročnících se úspěšnosti pohybovaly mezi $56 \%$ a $78 \%$, což je vyhovující. Ročníkové výsledky naznačují trend zhoršování průměrné úspěšnosti s věkem. Ten však není zcela průkazný.

Chlapci dosáhli vyšší průměrné úspěšnosti v matematickém testu, a to jak celkově, tak i v jednotlivých ročnících. Statisticky významný byl celkový rozdíl mezi dívkami a chlapci, $t(1381)=4,003, p<0,001$, a při detailnějším pohledu ve 4 . ročníku $(p<0,05)$, 7. ročníku $(p<0,05)$ a 8. ročníku $(p<0,05)$. Trend horších výsledků dívek je v datech zřetelný a pravděpodobně by se při větším výzkumném souboru projevil jako signifikantní i v ostatních věkových kategoriích.

\section{ZNÁMKA Z MATEMATIKY}

Známka z matematiky na vysvědčení představuje sumativní vnější hodnocení výkonů. Pokud jí žáci důvěřují, chápou ji jako důkaz vlastních matematických kompetencí, ale pokud ji nedůvěřují, je pro ně „pouze“ autoritativním vyjádřením bez větší informační hodnoty. Jak ovšem potvrzuje řada studií, známky relativně dobře korelují s úspěšností v aktuálních testech i s dlouhodobými vzdělávacími výsledky (např. Rubešová, 2009).

V našem výzkumu jsme zjištovali, jakou známku z matematiky žáci dostali na posledním vysvědčení. Podíl jednotlivých známek uvádí tab. 3. Analýza dospěla k několika očekávaným zjištěním: známka 5 je užívána zcela výjimečně; s narůstajícím ročníkem se rozšiřuje škála používaných známek; s narůstajícím ročníkem se

Tab. 3: Podíl známek (v \%) a průměrná známka z matematiky

\begin{tabular}{cccccc}
\hline Ročník & známka 1 & známka 2 & známka 3 & známka 4 & známka 5 \\
\hline 4 & 74,1 & 21,9 & 3,7 & 0,3 & 0,0 \\
\hline 5 & 58,8 & 33,3 & 7,1 & 0,7 & 0,0 \\
\hline 6 & 33,2 & 48,7 & 15,5 & 2,5 & 0,0 \\
\hline 7 & 34,3 & 44,4 & 17,4 & 3,4 & 0,6 \\
\hline 8 & 22,1 & 49,5 & 22,6 & 5,8 & 0,0 \\
\hline 9 & 16,9 & 48,6 & 24,3 & 9,5 & 0,7 \\
\hline Celkem & 44,3 & 39,1 & 13,4 & 3,0 & 0,1 \\
\hline
\end{tabular}


posouvá těžiště známek od výborně $\mathrm{k}$ dobře. Napříč sledovanými šesti ročníky se známka v průměru zhoršila o jeden stupeň (z 1,3 na 2,3). Průměrné známky dívek a chlapců se signifikantně neliší, a to ani v celém souboru, ani napříč jednotlivými ročníky.

\section{Pocit KOMPETENCE V MATEMATice}

Psychologické výzkumy dlouhodobě prokazují zásadní vliv přesvědčení o vlastních kompetencích na úspěšné uplatňování znalostí a dovedností (Mullis et al., 2012; Usher \& Pajares, 2009). Pokud žáci disponují určitými znalostmi, ale nejsou přesvědčeni o tom, že je mají a že s nimi dokáží správně řešit konkrétní úkoly, jejich výkony jsou tím sníženy, a naopak. V dotazníku jsme proto zjištovali, jak kompetentní se žáci v matematice cítí. Vybírali přitom ze tří možných odpovědí o matematice coby školním předmětu (v porovnání s ostatními předměty) - jde mi dobře (1), jde mi prüměrně (2) a moc mi nejde (3).

V celém souboru hodnotilo matematiku jako předmět, který jim dobře jde, $47 \%$ žáků, naopak jako předmět, který jim moc nejde, ji vnímá $10 \%$ žáků. Graf 2 ukazuje podíl jednotlivých odpovědí podle ročníků. Jasně z něho vyplývá, že s věkem dochází $\mathrm{k}$ poklesu podílu žáků, kteří se cítí $\mathrm{v}$ matematice kompetentní. Odpověd' jde mi dobře zvolilo téměř $60 \%$ nejmladších žáků, ale jen necelých $30 \%$ v nejstarších skupinách. V celém souboru i ve všech ročnících s výjimkou 6 . a 8. ročníku se chlapci cítili v matematice signifikantně kompetentnější než dívky $(p<0,001$ a $p<0,05)$, a to i při kontrole známky z matematiky. To znamená, že i ve skupině těch, kteří na vysvědčení z matematiky obdrželi shodnou známku, důvěřovali chlapci svým kompetencím více než dívky.

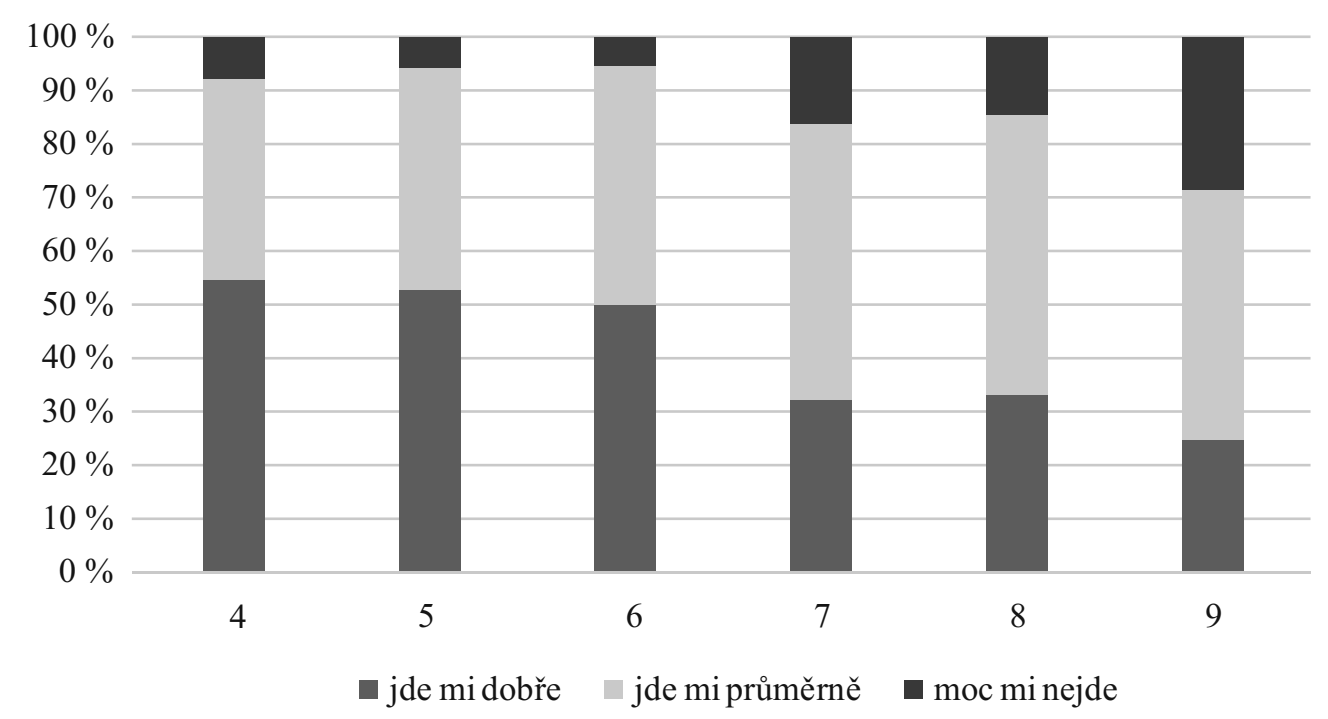

Graf 2: Podíl míry pocitu kompetence v matematice u žáků 4. až 9. ročníku

\section{MATEMATICKÁ SELF-EFFICACY}

Pocit kompetence může být zjištován také komplexnějšími zpo̊soby, než je výše uvedená otázka na subjektivní odhad úspěšnosti v předmětu. Jedním z nich je měření self-efficacy, která představuje „přesvědčení lidí o jejich schopnostech nutných k dosažení určitých výkonư (Bandura, 1994: s. 2). Ceský termín není ustálen v odborné literatuře lze nalézt označení osobní zdatnost, vnímaná osobní účinnost, obecná vlastní efektivita atd., a proto navrhujeme používat anglické označení self-efficacy. Četné psychologické výzkumy prokazují silný vliv self-efficacy na budování 
znalostí a dovedností, na vyšší testové výkony a na častější volbu studijních a profesních drah s významnou rolí matematiky (např. Pajares \& Graham, 1999; Hoffman, 2010). Rovněž některé české studie již potvrzují roli self-efficacy v žákovských výkonech.

Pro měření matematické self-efficacy na základní škole byla vyvinuta specifická škála (Smetáčková \& Vozková, 2016). Původní škála zahrnovala 30 položek, ovšem pro účely zde představeného výzkumu byla zredukována na 10 položek. Znění položek je uvedeno $\mathrm{v}$ tab. 4. Všechny položky byly hodnoceny na pětibodové škále od 1 (souhlasím) po 5 (nesouhlasím). Součet jednotlivých odpovědí tvoří souhrnný skór, který může nabývat hodnot od 10 do 50, přičemž pro interpretaci platí, že čím nižší celkový skór, tím vyšší matematická self-efficacy. Psychometrické charakteristiky redukované škály (šikmost, strmost, diskriminace) se ukázaly jako vyhovující. Reliabilita měřena Cronbachovou alfa dosáhla hodnoty 0,812.

Tab. 4: Průměrný skór a směrodatná odchylka v redukované škále matematické self-efficacy

\begin{tabular}{|c|c|c|c|c|c|c|}
\hline & \multicolumn{3}{|c|}{ Průměrný skór } & \multicolumn{3}{|c|}{ Směrodatná odchylka } \\
\hline & Celkem & Dívky & Chlapci & Celkem & Dívky & Chlapci \\
\hline $\begin{array}{l}\text { 1. Matematika se mi zdá } \\
\text { celkem jednoduchá. }\end{array}$ & 2,23 & 2,35 & 2,10 & 1,071 & 1,048 & 1,080 \\
\hline $\begin{array}{l}\text {. Když se v matematice } \\
\text { učíme něco nového, věřím, } \\
\text { že to pochopím. }\end{array}$ & 1,81 & 1,88 & 1,73 & 0,963 & 0,984 & 0,935 \\
\hline $\begin{array}{l}\text { 3. Pro mé rodiče je } \\
\text { důležité, aby mi } \\
\text { matematika šla. }\end{array}$ & 1,75 & 1,77 & 1,74 & 1,052 & 1,061 & 1,043 \\
\hline $\begin{array}{l}\text { 4. Učitel/ka matematiky } \\
\text { mě často chválí, že mi } \\
\text { matematika jde. }\end{array}$ & 2,81 & 2,89 & 2,73 & 1,265 & 1,252 & 1,274 \\
\hline
\end{tabular}

\begin{tabular}{lllllll}
\hline 5. Když se mi nepovede & 1,88 & 1,86 & 1,91 & 1,093 & 1,059 & 1,128
\end{tabular}
vyřešit matematickou úlohu napoprvé, zkusím to

znovu.

\begin{tabular}{lllllll}
\hline 6. Lidé kolem mě si myslí, & 2,74 & 2,87 & 2,60 & 1,264 & 1,245 & 1,271
\end{tabular}
že mám dobré

matematické schopnosti.

\begin{tabular}{lllllll}
\hline 7. Během hodin & 1,73 & 1,64 & 1,82 & 0,899 & 0,862 & 0,927
\end{tabular}
matematiky se snažím soustředit a dávat pozor.

\begin{tabular}{|c|c|c|c|c|c|c|}
\hline $\begin{array}{l}\text { 8. Dělám vše proto, abych } \\
\text { měl(a) z matematiky } \\
\text { dobré známky. }\end{array}$ & 1,61 & 1,57 & 1,66 & 0,882 & 0,863 & 0,900 \\
\hline $\begin{array}{l}\text { 9. Chci pracovat } \\
\text { v zaměstnání, jehož } \\
\text { součástí je matematika. }\end{array}$ & 3,19 & 3,38 & 3,00 & 1,421 & 1,383 & 1,436 \\
\hline $\begin{array}{l}\text { 10. Záleží mi na tom, jestli } \\
\text { se mi v matematice daří. }\end{array}$ & 1,57 & 1,56 & 1,59 & 0,856 & 0,872 & 0,839 \\
\hline Celkem - suma & 20,89 & 21,29 & 20,47 & 6,393 & 6,374 & 6,391 \\
\hline
\end{tabular}


Celkový průměrný skór byl poměrně nízký ( 21 bodů z 50 ), což znamená, že zúčastnění žáci mají poměrně vysokou matematickou self-efficacy. Analýza po ročnících ale ukázala jasný trend poklesu matematické self-efficacy s věkem. Průměrný skór ve 4 . ročníku byl 18,12, zatímco v 9 . ročníku 24,36 .

Redukovaná škála ověřovala několik aspektů matematické self-efficacy, kterými byla důvěra ve své schopnosti, získávání pozitivní zpětné vazby od okolí a snaha krátkodobě i dlouhodobě uspět v matematice. Výsledky v dílčích položkách ukazují, že studující se snaží ve školní matematice dosáhnout dobrých výkonů a že poměrně dost důvěřují svým matematickým schopnostem, ovšem $\mathrm{v}$ podstatně menší míře dostávají podporu ze strany svých vyučujících i dalších významných osob a rovněž většina neplánuje věnovat se matematice v dlouhodobém horizontu. Obdobné výsledky se prokázaly ve všech ročnících.

Rozdíl v celkové self-efficacy mezi dívkami a chlapci se ukázal statisticky významný, $t(1376)=2,382, p<0,05$, a to v neprospěch dívek. Podobně jako u pocitu matematické kompetence tedy chlapci dosáhli lepších výsledků - více svým schopnostem důvěřují. Při detailnějším pohledu do jednotlivých ročníků sice výsledky naznačují stejný vzorec, tj. nižší self-efficacy dívek, avšak pouze v 8. ročníku se jednalo o rozdíl statisticky významný $(p<0,05)$.

\section{VYSVĚTLENÍ OBLIBY MATEMATIKY}

Naší základní výzkumnou otázkou bylo, zda obliba matematiky coby školního předmětu souvisí spíše se žákovským sebehodnocením (aktuálním a dlouhodobým), nebo $\mathrm{s}$ vnějším hodnocením (známkou a výsledkem $\mathrm{v}$ testu). Abychom mohli na tuto otázku odpovědět, věnovali jsme se $\mathrm{v}$ analýzách nejprve korelacím mezi oblibou a jednotlivými proměnnými a poté hledání vysvětlujících modelů s použitím regresní analýzy.

Korelační analýzy ukázaly výrazně silnější vztahy mezi oblibou matematiky a žákovským sebehodnocením než mezi oblibou matematiky a externím hodnocením. Zatímco v prvním případě se hodnoty korelačních koeficientů pohybovaly mezi 0,44 a 0,58, v druhém př́ípadě byly zhruba poloviční. Je však třeba zdůraznit, že se síla korelací lišila napříč ročníky.

Tabulka 5 ukazuje jednotlivé hodnoty Pearsonova korelačního koeficientu mezi oblibou a sledovanými proměnnými. Údaje potvrzují, že všechny čtyři proměnné mají signifikantně vysokou korelaci s oblibou matematiky. S věkem se jednoznačně

Tab. 5: Korelační koeficienty mezi oblibou matematiky a sledovanými proměnnými

\begin{tabular}{ccccc}
\hline Ročník & $\begin{array}{c}\text { známka } \\
\text { z matematiky }\end{array}$ & $\begin{array}{c}\text { úspěšnost } \\
\text { v testu }\end{array}$ & $\begin{array}{c}\text { pocit } \\
\text { kompetence }\end{array}$ & $\begin{array}{c}\text { matematická } \\
\text { self-efficacy }\end{array}$ \\
\hline 4 & 0,013 & $-0,146^{*}$ & $0,547^{* *}$ & $0,493^{* *}$ \\
\hline 5 & $0,125^{*}$ & $-0,125^{*}$ & $0,580^{* *}$ & $0,516^{* *}$ \\
\hline 6 & $0,147^{*}$ & $-0,154^{*}$ & $0,521^{* *}$ & $0,515^{* *}$ \\
\hline 7 & $0,273^{* *}$ & $-0,157^{*}$ & $0,466^{* *}$ & $0,493^{* *}$ \\
\hline 8 & $0,211^{* *}$ & $-0,134$ & $0,443^{* *}$ & $0,483^{* *}$ \\
\hline 9 & $0,382^{* *}$ & $-0,378^{* *}$ & $0,563^{* *}$ & $0,650^{* *}$ \\
\hline Celkem & $0,282^{* *}$ & $-0,227^{* *}$ & $0,550^{* *}$ & $0,572^{* *}$ \\
\hline
\end{tabular}

Poznámka: **znamená, že korelace je statisticky významná na hladině 0,01 , *znamená, že korelace je statisticky významná na hladině 0,05 . 
zvyšuje souvislost mezi oblibou matematiky a známkami z matematiky na vysvědčení. Na druhou stranu se ale výrazně a systematicky nezvyšuje souvislost ani s výsledky v matematickém testu, ani se sebehodnocením. Výjimku tvoří žáci 9. ročníku, kde se souvislost se všemi čtyřmi proměnnými ukázala jako relativně vysoká. To může být ovlivněno tím, že v 9 . ročníku musí žáci provádět volbu další vzdělávací dráhy, a proto zaujímají k matematice jednoznačný postoj, v němž se pod tlakem očekávání budoucnosti (více než v nižších ročnících) zrcadlí i jejich uvědomění svých kompetencí.

Rozdíly mezi chlapci a dívkami byly prokázány v případě známky z matematiky, která silněji korelovala u chlapců $(0,318)$ než u dívek $(0,259)$, a u matematického testu, který rovněž silněji koreloval u chlapců $(-0,254)$ než u dívek $(-0,187)$. Oba trendy se projevily i napříč většinou ročníků. Naopak ani u jedné ze sebehodnotících proměnných se větší rozdíl mezi dívkami a chlapci neukázal. To by naznačovalo, že externí evaluace má v př́padě chlapců silnější vliv na oblibu matematiky a naopak.

Síla vztahu mezi oblibou matematiky a sledovanými proměnnými se potvrdila i analýzou průměrných hodnot při třídění podle míry obliby matematiky. Ta mohla nabývat tří variant, přičemž žáci volící jednotlivé varianty se od sebe vzájemně signifikantně lišili ve všech čtyřech sledovaných proměnných. Údaje jsou uvedeny v tab. 6.

Tab. 6: Průměrné hodnoty jednotlivých proměnných podle stupně obliby matematiky

\begin{tabular}{lcccc}
\hline Obliba matematiky & $\begin{array}{c}\text { známka } \\
\text { z matematiky } \\
(1-5)\end{array}$ & $\begin{array}{c}\text { úspěšnost } \\
\text { v testu } \\
(0-100)\end{array}$ & $\begin{array}{c}\text { pocit } \\
\text { kompetence } \\
(1-3)\end{array}$ & $\begin{array}{c}\text { matematická } \\
\text { self-efficacy } \\
(10-50)\end{array}$ \\
\hline Oblíbený předmět $(n=612)$ & 1,53 & $72,3 \%$ & 1,27 & 17,26 \\
\hline Nevadí mi $(n=520)$ & 1,87 & $63,0 \%$ & 1,81 & 22,64 \\
\hline Neoblíbený předmět $(n=200)$ & 2,15 & $58,7 \%$ & 2,26 & 27,35 \\
\hline
\end{tabular}

Z uvedené tabulky vyplývá, že ti, kteři matematiku označili za svůj oblíbený školní předmět, dosahovali jak lepších výsledků v sebehodnocení, tak v externím hodnocení, a naopak. Nalezený vztah je nutné interpretovat otevřeně - bud' jako důsledek určité míry obliby (tj. v oblíbeném předmětu roste motivace, která se projeví v reálně lepších výkonech, a tedy i v opodstatněném pozitivnějším externím hodnocení), nebo naopak jako jeho prř́činu (tj. v předmětu, v němž má žák dobré výkony, dostává pozitivní zpětnou vazbu a vnímá se jako kompetentní, a proto se pro něj tento předmět následně stává oblíbeným). Pro vysvětlení směru vztahu by bylo nutné realizovat longitudinální výzkum.

Nicméně již ve stávající studii je možné vztah mezi proměnnými prozkoumat blíže pomocí lineární regrese. Ta dovoluje zjistit to, které nezávislé proměnné dokáží predikovat oblibu matematiky. Do testovaných modelů byla jako nezávislá proměnná zahrnuta známka, úspěšnost $\mathrm{v}$ testu, matematická self-efficacy, pocit kompetence (model 1) a dále ročník a gender (model 2). Závislou proměnou byla obliba matematiky, která nabývá hodnoty od 1 (oblíbený předmět) přes 2 (předmět mi nevadí) do 3 (neoblíbený předmět). Metoda Enter ukázala, že modely jsou funkční a vysvětlují $41 \%$, resp. $43 \%$ variance.

Tabulka 7 obsahuje hlavní nestandardizované a standardizované koeficienty pro model 1 a 2 . V modelu 1 byly tři ze čtyř zahrnutých proměnných statisticky významné a jako nevýznamná se ukázala známka z matematiky. Protože z dílčích analýz vyplývaly rozdíly mezi dívkami a chlapci a mezi ročníky, zahrnuli jsme do druhého modelu navíc i tyto dvě proměnné. V rozššřreném modelu 2 byly statis- 
Tab. 7: Výsledky lineární regrese pro oblibu matematiky

\begin{tabular}{lrrrrrr} 
& \multicolumn{3}{c}{ Model 1 } & \multicolumn{3}{c}{ Model 2 } \\
\cline { 2 - 7 } Prediktor & \multicolumn{1}{c}{ Beta } & Sign. & $B$ & Beta & Sign. \\
\hline Obliba matematiky (konstanta) & 0,091 & & $<0,376$ & $-0,027$ & & $<0,871$ \\
\hline Známka z matematiky & $-0,046$ & $-0,052$ & $<0,069$ & $-0,076$ & $-0,087$ & $<0,003$ \\
\hline Matematický test & 0,111 & 0,036 & $<0,001$ & 0,122 & 0,040 & $<0,142$ \\
\hline Matematická self-efficacy & 0,046 & 0,415 & $<0,001$ & 0,042 & 0,379 & $<0,001$ \\
\hline Pocit kompetence v matematice & 0,391 & 0,358 & $<0,001$ & 0,392 & 0,359 & $<0,001$ \\
\hline Ročník & - & - & - & 0,056 & 0,131 & $<0,001$ \\
\hline Gender & - & - & - & $-0,065$ & $-0,046$ & $<0,033$ \\
\hline
\end{tabular}

ticky významnými pět ze šesti proměnných, přičemž jako nevýznamná se ukázala úspěšnost v matematickém testu. Oba regresní modely tedy prokázaly signifikantní vliv míry matematické self-efficacy a pocitu vlastní kompetence v matematice, přičemž druhý faktor je mírně silnějším prediktorem. Pokud skór pocitu matematické kompetence stoupne o jeden bod, obliba matematiky se zvýší o 0,39. Je ovšem třeba doplnit, že pocit matematické kompetence a matematická self-efficacy vzájemně silně korelují, čímž závěr o vyšším vlivu pocitu matematické kompetence (navzdory jejím větším hodnotám $B$ ) klesá na relevanci. Korelační vztah mezi oblibou matematiky na jedné straně a matematickou kompetencí či matematickou self-efficacy na druhé straně je přibližně shodný (viz tab. 5), pouze s mírně silnějším vztahem v případě matematické kompetence u mladších žáků a naopak mírně silnějším vztahem v případě matematické self-efficacy u starších žáků.

\section{DISKUSE}

Zde prezentovaná studie se snažila zjistit, zda obliba matematiky má souvislost s externím hodnocením a sebehodnocením, případně s kterým z nich je souvislost silnější. Výsledky studie ukázaly, že užší vazba existuje mezi oblibou a sebehodnocením v matematice a funguje jako její silnější prediktor než externí hodnocení. V rámci sebehodnocení se prediktivní hodnoty pocitu matematické kompetence a matematické self-efficacy ukázaly přibližně shodné. Na základě předchozích výzkumů (např. Inzlicht \& Schmader, 2008; Chvál, 2013) jsme předpokládali, že silnějším prediktorem bude matematická self-efficacy, která představuje komplexní a dlouhodobé přesvědčení o účinnosti vlastních matematických schopností. V naší studii ale obdobnou sílu (u mladších dětí dokonce mírně větší sílu) prokázala jednoduchá, jednodimenzionální škála zjištující, v jaké míře se žákům v matematice coby školnímu předmětu daří. Naše studie tak nepotvrdila hypotézu 3 (Obliba matematiky silněji souvisí s matematickou self-efficacy než s prospěchem, pocitem vlastni kompetence a aktuální úspěšností). Z praktického hlediska školní diagnostiky se jedná o pozitivní výsledek, nebot dotaz na pocit kompetence je v pedagogické praxi snazší a rychlejší než redukovaná či plná verze škály matematické self-efficacy (Smetáčková \& Vozková, 2016). Jedná se však o výsledek mírně překvapující v mezinárodním kontextu, protože zahraniční studie opakovaně a např́ič různými věkovými kategoriemi potvrzují silnou souvislost mezi self-efficacy a oblibou matematiky (Pajares \& Graham, 1999). Tento rozpor může vyplývat z toho, že čeští žáci, jak bývá někdy uváděno, mají slaběji rozvinutou sebereflexi, která je základem matematické self-efficacy, ale v menší míře nestrukturovaného pocitu matematické kompetence. Obě proměnné se pak mohou 
víceméně redukovat na sebe navzájem, což by odpovídalo i vysoké vzájemné korelaci mezi nimi.

Naše studie sledovala ještě další dvě hypotézy. Hypotéza 1 ( $S$ narůstajícím věkem klesá obliba matematiky) byla potvrzena. Trend snižování obliby matematiky mezi 4. a 9. ročníkem byl jednoznačně potvrzen, přičemž podobně jako v jiných výzkumech byl výraznější pokles zaznamenán na začátku 2. stupně ZŠ (Hrabal \& Pavelková, 2012). Podobně jako Chvál (2013) ale vnímáme dosud nezodpovězenou otázku, do jaké míry je pokles obliby dán nástupem puberty, která přináší posun v zájmech, nebo povahou kurikula a vyučovacích metod.

Další sledovaná hypotéza se týkala genderových rozdílů (Chlapci považuji matematiku za oblíbenější předmět než dívky). Naše studie, podobně jako předchozí zahraniční (Mullis et al., 2012) a zejména české (Hrabal \& Pavelková, 2012; Chvál, 2013; Federičová \& Münich, 2015), potvrdila vyšší oblibu matematiky na straně chlapců. Rovněž se ukázalo, že chlapci dosáhli vyšší úspěšnosti v matematickém testu i vyššího sebehodnocení.

\section{ZÁVĚR}

Jelikož bylo opakovaně výzkumně potvrzeno, že čím oblíbenějším předmětem matematika pro žáky je, tím lepší jsou jejich školní výkony v této oblasti, je logické, že se vyučující snaží hledat způsoby, jak zvýšit oblibu matematiky (Hoffman, 2010; Pajares \& Graham, 1999). Cesty, jejichž efektivita se nejčastěji ověřuje, se týkají úpravy vyučovacích metod směrem $\mathrm{k}$ intenzivnějšímu zapojení interaktivních technik a postupů vycházejících z pedagogického konstruktivismu. Vedle toho ale doporučujeme ověřovat také vliv zvýšení pocitu matematické kompetence a matematické self-efficacy u žáků. Ty se v naší studii ukázaly jako silnější prediktor obliby matematiky než externí hodnocení.

Je přitom důležité zdůraznit, že pocit matematické kompetence vyrůstá z opakované a reflektované zkušenosti se zvládnutím úkolu. Vyžaduje tedy, aby žáci měli možnost $\mathrm{v}$ matematice řešit různé typy úloh a byli podporováni v pestrosti možných řešení tak, že i žáci s odlišnými individuálními kognitivními a učebními styly mohou zažít úspěch. Dále by žáci měli být vyučujícími podporováni v uvědomování si toho, jakými postupy dosáhli úspěšného řešení a v čem jsou jejich silné i slabé stránky. V takovém případě totiž žáci nejsou závislí na externím hodnocení, které není pro žákovskou preferenci matematiky tak důležitým faktorem. Ale naopak posilují vlastní sebehodnocení, a tím i autoregulaci učebního procesu, což zvyšuje dlouhodobou efektivitu učení (Ramdass \& Zimmerman, 2008).

\section{PODĚKOVÁNí}

Tento článek vznikl v rámci grantového projektu Slovní úlohy jako klič k aplikaci a porozuměni matematickým pojmưm (GA16-06134S) financovaného Grantovou agenturou Čské republiky.

\section{LITERATURA}

Bandura, A. (1994). Self-efficacy. In V. S. Ramachandran (Ed.), Encyclopedia of human behavior. Vol. 4. San Diego, CA: Academic Press. 
Federičová, M. \& Münich, D. (2015). Srovnání žákovské obliby školy a matematiky pohledem mezinárodních šetření. Pedagogická orientace, 25(4), 557-582.

Hoffman, B. (2010). "I think I can, but I'm afraid to try": The role of self-efficacy beliefs and mathematics anxiety in mathematics problem-solving efficiency. Learning and Individual Differences, 20(3), 276-283.

Hrabal, V. \& Pavelková, I. (2010). Jaký jsem učitel. Praha: Portál.

Chvál, M. (2013). Změna postojů českých žáků k matematice během školní docházky. Orbis scholae, 7(3), 49-71.

Inzlicht, M. \& Schmader, T. (2012). Stereotype threat: Theory, process, and application. Oxford: University Press.

Mullis, I. V.S., Martin, M. O., Foy, P. \& Arora, A. (2012). TIMSS 2011 International results in mathematics. Chestnut Hill: TIMSS \& PIRLS International Study Center, Boston College.

Pavelková, I. \& Hrabal, V. (2012). Mathematics in perception of pupils and teachers. Orbis scholae, 6(2), 119-132. Dostupné z http://www.orbisscholae.cz/archiv/2012/2012_2_08.pdf

Pajares, F. \& Graham, L. (1999). Self-efficacy, motivation constructs, and mathematics performance of entering middle school students. Contemporary Educational Psychology, $24(2), 124-139$.

Pöschl, R. (2011). Postoje žáků ke škole. Dotazník pro žáky. Praha: NÚOV. Dostupné z http://www.nuv.cz/file/71/

Ramdass, D. \& Zimmerman, B. J. (2008). Effects of self-correction strategy training on middle school students' self-efficacy, self-evaluation, and mathematics division learning. Journal of advanced academics, 20(1), 18-41.

Rubešová, J. (2009). Souvisí úspěšnost studia na vysoké škole se středoškolským prospěchem? Pedagogická orientace, 19(3), 89-103.

Smetáčková, I. \& Vozková, A. (2016). Matemetická self-efficacy a její měření v průběhu základní školy. E-psychologie, 10(1), 18-33.

Usher, E. L. \& Pajares, F. (2009). Sources of self-efficacy in mathematics: A validation study. Contemporary educational psychology, 34(1), 89-101.

IRENA SMETÁČKOVÁ, irena.smetackova@pedf.cuni.cz

Univerzita Karlova, Pedagogická fakulta

Katedra psychologie

Magdalény Rettigové 4, Praha 1, Česká republika 